\title{
Identification of the designer benzodiazepine 8-chloro-6-(2-fluorophenyl)-1-methyl-4H-[1,2,4]triazolo[4,3-a][1,4] benzodiazepine (flualprazolam) in an anesthesia robbery case
}

\author{
Zhenhua Qian $^{1}$ - Cuimei Liu ${ }^{2}$ Jian Huang ${ }^{1} \cdot$ Qingqing Deng ${ }^{3} \cdot$ Zhendong Hua $^{2}$
}

Received: 24 June 2019 / Accepted: 20 August 2019 / Published online: 30 September 2019

(c) The Author(s) 2019

\begin{abstract}
Purpose This publication reports analytical properties of the designer benzodiazepine 8-chloro-6-(2-fluorophenyl)-1-methyl$4 H$-[1,2,4]triazolo[4,3-a][1,4]benzodiazepine (flualprazolam) seized in an anesthesia robbery case.

Methods The target compound was identified by liquid chromatography-quadrupole time-of-flight-mass spectrometry (LCQTOF-MS), gas chromatography-mass spectrometry (GC-MS), and nuclear magnetic resonance (NMR) spectroscopy.

Results We could obtain detailed analytical data of flualprazolam - a new designer benzodiazepine available on the designer drug market.

Conclusions More designer benzodiazepines have been detected and seized on the illegal drug scene as new psychoactive substances during the last 5 years. In this study, we presented analytical data of flualprazolam to assist forensic laboratories that encounter these newly emerging compounds in casework. This is the first report on this compound in illegal products.
\end{abstract}

Keywords New psychoactive substance $\cdot$ Designer benzodiazepine $\cdot$ Flualprazolam $\cdot$ Alprazolam $\cdot$ Flubromazolam .

Anesthesia robbery case

\section{Introduction}

In recent years, a large number of new psychoactive substances (NPS) have emerged on the drugs market, with 899 substances being reported to the United Nations Office on Drugs and Crime (UNODC) in 2019 [1]. Many different classes of NPS, such as synthetic cannabinoids, synthetic cathinones, phenethylamines, piperazines, and plant-based substances, etc., have been encountered by law enforcement

Zhenhua Qian

sunny1343@126.com

$\triangle$ Zhendong Hua

zdhuapku@163.com

1 Institute of Forensic Science of the Ministry of Public Security, No. 17 Muxidi Nanli, West City District, Beijing 100038, China

2 National Narcotics Laboratory, Drug Intelligence and Forensic Center of the Ministry of Public Security, No. 18 Dongbeiwang West Road, Haidian District, Beijing 100193, China

3 Zunyi Public Security Bureau of Guizhou Province, Zunyi 563400, China
[2]. During the last 5 years, new psychoactive substances designer benzodiazepines (DBZDs) have been detected and seized on the illegal drug scene. In 2012, the first DBZDs were offered in Internet shops as an alternative to prescription only benzodiazepines (BZDs) [3-5].

DBZDs have related structures to therapeutically used BZDs, but are not used for medical purposes. BZDs are mainly used as hypnotics/sedatives, anesthetics, tranquilizers, anticonvulsants, and muscle relaxants, but also treat panic disorder, or acute epileptic seizure. Abuse of classical BZDs used for medical treatment may lead to addiction, tolerance, or various intoxications. The potential risk of abusing DBZDs is not only addiction, but also serious health complications and consequences, as the pharmacology and toxicology of DBZDs are not thoroughly described, unlike BZDs used for the legal therapy. It is also necessary to note that DBZDs can be misused together with other drugs such as ethanol, central nervous system (CNS) depressants, marijuana, and other psychoactive drugs which can be potent in their negative effects on human organisms $[6,7]$.

In November 2017, an anesthesia robbery case took place, and two bottles of liquid purchased from the Internet were seized. The DBZD 
8-chloro-6-(2-fluorophenyl)-1-methyl-4H-[1,2,4] triazolo[4,3-a][1,4]benzodiazepine (flualprazolam) was identified in the liquid. This article reports on the analytical properties of this compound. Flualprazolam is very similar to alprazolam and flubromazolam in structure. Their structures are shown in Fig. 1. Structure elucidation was carried out by means of liquid chromatography-quadrupole time-offlight-mass spectrometry (LC-QTOF-MS), gas chromatography-mass spectrometry (GC-MS), and nuclear magnetic resonance (NMR) spectroscopy.

Alprazolam is used to treat anxiety, depression, and insomnia as BZD. Flubromazolam was first patented in 1978 and was first reported to the European Monitoring Centre for Drugs and Drug Addiction (EMCDDA) in 2014 as DBZD for illegal use [8]. The pharmacological properties of flubromazolam have been reported by Manchester et al. [3] and Łukasik-Głębocka et al. [9]. Flubromazolam is a DBZD with a strong and long-lasting depressive effect on the CNS representing a high risk of severe poisoning complicated by hypoxial ischemic changes in the CNS. Ingestion of $3 \mathrm{mg}$ of flubromazolam $19 \mathrm{~h}$ prior to hospitalization has been reported by a patient; severe respiratory failure, hypotension, CNS depression, and brain damage were observed [3, 9]. Flualprazolam was first patented in 1970 , but has since not been found in the illicit abuse market [10]. Regarding flualprazolam, no analytical data could be found in the literature, and this is the first report on this compound in illegal products [11].

\section{Case history}

A 21-year-old girl went to the public security authority to report the case, claiming that she experienced dizziness after drinking tea with a male "netizen" in a teahouse the previous night. She was unconscious and woke up at approximately 5 a.m. to find herself in a hotel room. She also discovered that her wallet and cell phone were stolen. A few days later, the suspect was captured. The police found two bottles of colorless and transparent liquid in his home (named Lie Yan). The

Fig. 1 Chemical structures of flualprazolam, alprazolam, and flubromazolam suspect made a statement that he added the named 'Lie Yan' liquid to the victim's drinks. The victim was confused $1 \mathrm{~h}$ after taking the drug, fell asleep $2 \mathrm{~h}$ later, and then woke up a further $2 \mathrm{~h}$ after.

We did a quick test for the liquid using various drug rapid test kits and found that the liquid contained BZD(s).

\section{Materials and methods}

\section{Materials}

Methanol and formic acid were obtained from Merck Chemicals (Darmstadt, Germany). Acetonitrile was obtained from Fisher Scientific (Aalst, Belgium). All reagents used in the analyses were of HPLC grade. Distilled water was obtained by reverse diffusion in a Millipore system (EMD Millipore, Billerica, MA, USA). For NMR, deuterated methanol $\left(\mathrm{CD}_{3} \mathrm{OD}, 99.8 \%\right)$ was purchased from Cambridge Isotope Laboratories (Tewksbury, MA, USA). Alprazolam was purchased from National Institutes for Food and Drug Control (Beijing, China). Flubromazolam $(1.0 \mathrm{mg} / \mathrm{mL}$ in methanol) was purchased from Cerilliant (Round Rock, TX, USA).

\section{Sample preparation}

For GC-MS analysis, $5 \mathrm{~mL}$ of liquid sample was extracted by ethyl acetate $(1: 1, \mathrm{v} / \mathrm{v})$, concentrated to dry, and dissolved in $1 \mathrm{~mL}$ of methanol and sonicated for $10 \mathrm{~min}$ followed by filtration $(0.45 \mu \mathrm{m}$ filter unit; EMD Millipore). For LC-QTOF-MS analysis, the prepared solution was diluted with $0.1 \%$ formic acid (v/v) in water and passed through a centrifugal filter $(0.22 \mu \mathrm{m}$ filter unit; EMD Millipore). For NMR analysis, about $15 \mathrm{mg}$ of the sample powder prepared by preparative liquid chromatography was dissolved in $1 \mathrm{~mL}$ of $\mathrm{CD}_{3} \mathrm{OD}$. Preparative liquid chromatography analysis was carried out using an Agilent 1200 Series (Agilent, Santa Clara, CA, USA). Separation was performed with ZORBAX SB-C18 column $(25 \mathrm{~cm} \times 21.2 \mathrm{~mm}$ i.d., $7 \mu \mathrm{m}$ particle diameter; Agilent) and methanol/water (70:30, v/v) as mobile

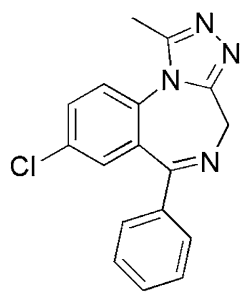

8-Chloro-6-phenyl-1-methyl$4 \mathrm{H}$-[1,2,4]triazolo[4,3a][1,4]benzodiazepine Alprazolam $\mathrm{C}_{17} \mathrm{H}_{13} \mathrm{ClN}_{4}: 308.8$<smiles>Cc1nnc2n1-c1ccc(Br)cc1C(c1ccccc1F)=NC2</smiles>

8-Bromo-6-(2-fluorophenyl)-1methyl-4H-[1,2,4]triazolo[4,3a] $[1,4]$ benzodiazepine

Flubromazolam $\mathrm{C}_{17} \mathrm{H}_{12} \mathrm{BrFN}_{4}: 371.2$ 
phase. The flow rate was set at $20 \mathrm{~mL} / \mathrm{min}$ and the injection volume was $0.2 \mathrm{~mL}$. Fifteen milligrams of the target compound with purity of great than $98 \%$ was obtained from $80 \mathrm{~mL}$ of the liquid sample.

\section{LC-QTOF-MS}

LC-QTOF-MS analysis was carried out using a Water Acquity UPLC (Waters, Milford, MA, USA) coupled with AB Sciex TripleTOF 5600 detector (AB Sciex, Framingham, MA, USA). Separation was performed at $40{ }^{\circ} \mathrm{C}$ with an Acquity UPLC CSH ${ }^{\mathrm{TM}} \mathrm{C} 18$ column $(10 \mathrm{~cm} \times 2.1 \mathrm{~mm}$ i.d., $1.7 \mu \mathrm{m}$ particle diameter; Waters). For gradient elution, the mobile phases $0.1 \%$ formic acid in water $(\mathrm{A})$ and acetonitrile (B) were mixed according to the following conditions: $0-1.5 \mathrm{~min} 2 \% \mathrm{~B}$, linear to $90 \% \mathrm{~B}$ up to $6.5 \mathrm{~min}$, hold at $90 \%$ to $9.4 \mathrm{~min}$, back to $2 \% \mathrm{~B}$ at $9.5 \mathrm{~min}$ and equilibration to $12 \mathrm{~min}$. The flow rate was $0.4 \mathrm{~mL} / \mathrm{min}$. The QTOF instrument was operated by electrospray ionization in the positive mode with the following parameters: ion spray voltage, $5.5 \mathrm{kV}$; turbo spray temperature, $600{ }^{\circ} \mathrm{C}$; nebulizer gas (gas 1), 50 psi; heater gas (gas 2), 50 psi; and curtain gas, 30 psi. Nitrogen was used as the nebulizer and auxiliary gas. Typical information acquisition consisted of two steps: the acquisition of a survey full-scan spectrum followed by a tandem mass spectrometry (MS/MS) experiment. The fullscan experiment was operated in high-resolution mode. The optimized declustering potential and collision energy were set at 80 and $5 \mathrm{~V}$, respectively. In the second experiment, a sweeping collision energy setting at $35 \pm 15 \mathrm{~V}$ was applied for collision-induced dissociation to obtain the fragment ions from the ions in the preceding scan. The full-scan and the MS/MS experiment were both operated in the mass range of $\mathrm{m} / \mathrm{z}, 50-1000$. Injection volume was $1 \mu \mathrm{L}$.

\section{GC-MS}

A Shimadzu 2010 gas chromatograph coupled with a QP2010 Plus mass selective detector (Shimadzu, Kyoto, Japan) was employed for the analysis. Chromatographic separation was carried out on a DB-5 MS capillary column ( $30 \mathrm{~m} \times 0.25 \mathrm{~mm}$ i.d., $0.25 \mu \mathrm{m}$ film thickness) (J\&W Scientific, Agilent, Palo Alto, CA, USA), and helium at a constant flow rate of $1.0 \mathrm{~mL} / \mathrm{min}$ was used as the carrier gas. The filtered solutions were injected in split mode (40:1) and the injection volume was $1 \mu \mathrm{L}$. The initial column temperature $140{ }^{\circ} \mathrm{C}$ was held for $3 \mathrm{~min}$, and then increased to $300{ }^{\circ} \mathrm{C}$ at a rate of $20{ }^{\circ} \mathrm{C} / \mathrm{min}$ and held at $300{ }^{\circ} \mathrm{C}$ for $16 \mathrm{~min}$. The GC injector and transfer line were maintained at 280 and $250^{\circ} \mathrm{C}$, respectively. The ion source was maintained at $230^{\circ} \mathrm{C}$. Ionization energy was set at $70 \mathrm{eV}$. Acquisition was carried out in a scan mode range of $m / z, 35-500$.
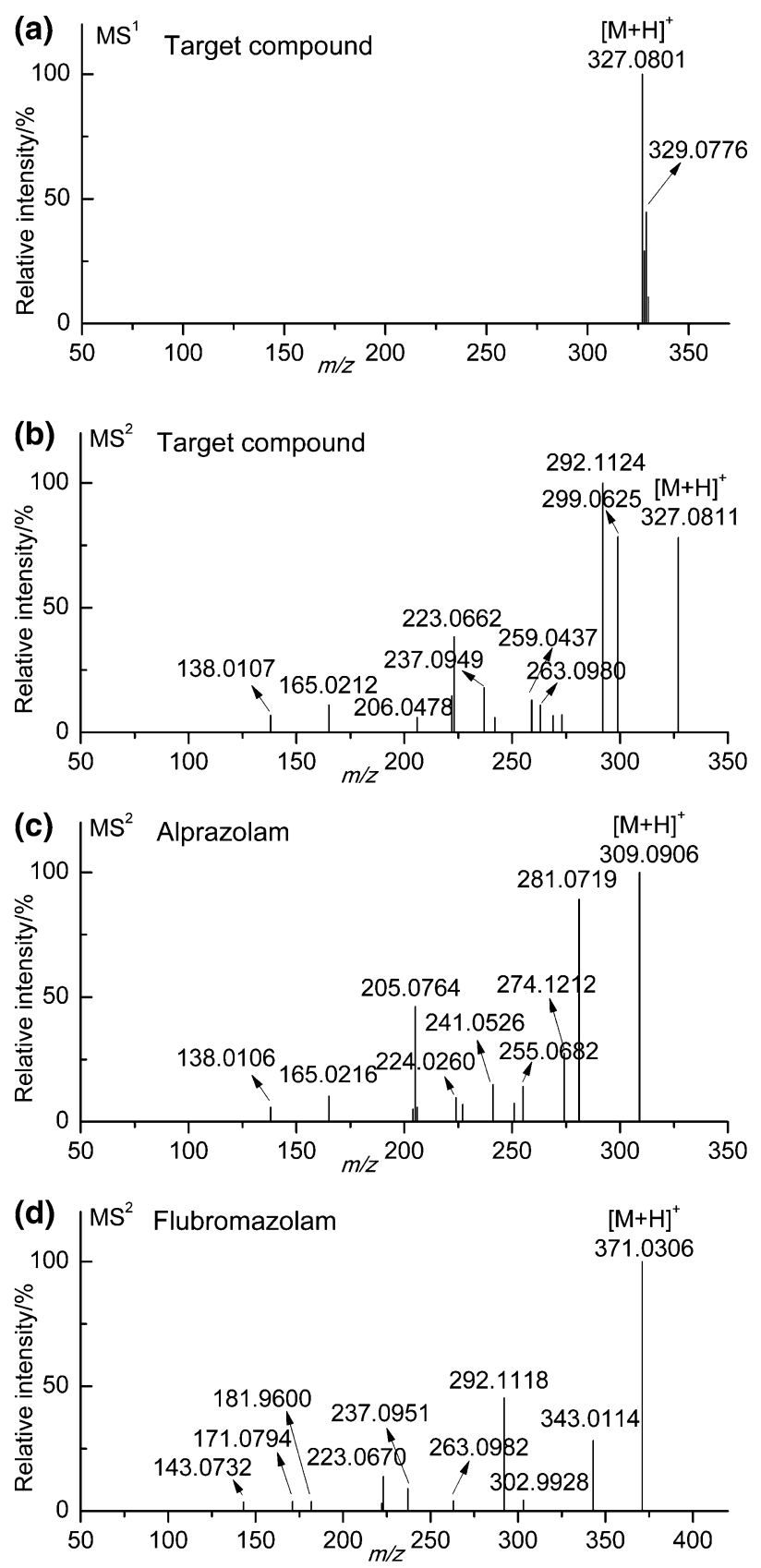

Fig. 2 Precursor ion spectrum of the target compound, and product ion spectra of the target compound, alprazolam and flubromazolam obtained by liquid chromatography-electrospray ionization-quadrupole time-of-flight-mass spectrometry

\section{NMR spectroscopy}

The NMR spectra were obtained on an Avance III 400 spectrometer (Bruker, Bremen, Germany) at $300 \mathrm{~K}$ with $400 \mathrm{MHz}$ for ${ }^{1} \mathrm{H}$ and $100 \mathrm{MHz}$ for ${ }^{13} \mathrm{C}$. Assignments were made via ${ }^{1} \mathrm{H}$-NMR, ${ }^{13} \mathrm{C}$-NMR, ${ }^{13} \mathrm{C}$-distortionless enhancement by polarization transfer $\left({ }^{13} \mathrm{C}\right.$-DEPT $),{ }^{1} \mathrm{H} /{ }^{1} \mathrm{H}$ correlation spectroscopy $\left({ }^{1} \mathrm{H} /{ }^{1} \mathrm{H}\right.$-COSY $),{ }^{1} \mathrm{H} /{ }^{13} \mathrm{C}$-heteronuclear 
single-quantum correlation spectroscopy $\left({ }^{1} \mathrm{H} /{ }^{13} \mathrm{C}-\mathrm{HSQC}\right)$, and ${ }^{1} \mathrm{H} /{ }^{13} \mathrm{C}$-heteronuclear multiple-bond correlation spectroscopy $\left({ }^{1} \mathrm{H} /{ }^{13} \mathrm{C}-\mathrm{HMBC}\right)$. The chemical shifts for ${ }^{1} \mathrm{H}$ and ${ }^{13} \mathrm{C}$ NMR spectra were referenced to internal reference tetramethylsilane.

\section{Results and discussion}

The LC-QTOF-MS spectrum of the target compound showed the protonated molecular ion $\left([\mathrm{M}+\mathrm{H}]^{+}\right)$at $\mathrm{m} / z 327.0801$ $\left(\mathrm{C}_{17} \mathrm{H}_{13} \mathrm{ClFN}_{4}{ }^{+}\right)$and an isotopic ion $[\mathrm{M}+2+\mathrm{H}]^{+}$at $\mathrm{m} / \mathrm{z}$ 329.0776 due to the presence of chlorine atom (Fig. 2a). The difference in the chemical formula between the target compound $\left(\mathrm{C}_{17} \mathrm{H}_{12} \mathrm{ClFN}_{4}\right)$ and alprazolam $\left(\mathrm{C}_{17} \mathrm{H}_{13} \mathrm{ClN}_{4}\right)$ was observed to be one fluorine. The difference in the chemical formula between flubromazolam $\left(\mathrm{C}_{17} \mathrm{H}_{12} \mathrm{BrFN}_{4}\right)$ and the
Table 1 Accurate masses of the protonated molecules and product ions and their proposed chemical formulae obtained for the target compound, alprazolam, and flubromazolam measured by liquid chromatographyquadrupole time-of-flight-mass spectrometry

\begin{tabular}{|c|c|c|c|c|}
\hline Compound & Chemical formula & Experimental mass & Theoretical mass & Error (ppm) \\
\hline \multirow[t]{14}{*}{ Target compound } & $\mathrm{C}_{17} \mathrm{H}_{13} \mathrm{ClFN}_{4}^{+}$ & 327.0811 & 327.0807 & 1.22 \\
\hline & $\mathrm{C}_{16} \mathrm{H}_{11} \mathrm{ClFN}_{3}^{+\cdot}$ & 299.0625 & 299.0620 & 1.67 \\
\hline & $\mathrm{C}_{17} \mathrm{H}_{13} \mathrm{FN}_{4}^{+\cdot}$ & 292.1124 & 292.1119 & 1.71 \\
\hline & $\mathrm{C}_{15} \mathrm{H}_{11} \mathrm{ClFN}_{2}^{+}$ & 273.0592 & 273.0589 & 1.10 \\
\hline & $\mathrm{C}_{15} \mathrm{H}_{7} \mathrm{ClFN}_{2}^{+}$ & 269.0281 & 269.0276 & 1.86 \\
\hline & $\mathrm{C}_{17} \mathrm{H}_{12} \mathrm{FN}_{2}^{+}$ & 263.0980 & 263.0979 & 0.38 \\
\hline & $\mathrm{C}_{14} \mathrm{H}_{9} \mathrm{ClFN}_{2}{ }^{+}$ & 259.0437 & 259.0433 & 1.54 \\
\hline & $\mathrm{C}_{14} \mathrm{H}_{6} \mathrm{ClFN}^{+}$ & 242.0169 & 242.0167 & 0.83 \\
\hline & $\mathrm{C}_{16} \mathrm{H}_{12} \mathrm{FN}^{+\cdot}$ & 237.0949 & 237.0948 & 0.42 \\
\hline & $\mathrm{C}_{14} \mathrm{H}_{8} \mathrm{FN}_{2}^{+}$ & 223.0662 & 223.0666 & -1.79 \\
\hline & $\mathrm{C}_{15} \mathrm{H}_{9} \mathrm{FN}^{+}$ & 222.0714 & 222.0714 & 0 \\
\hline & $\mathrm{C}_{10} \mathrm{H}_{9} \mathrm{ClN}_{3}^{+}$ & 206.0478 & 206.0480 & -0.97 \\
\hline & $\mathrm{C}_{8} \mathrm{H}_{6} \mathrm{ClN}_{2}{ }^{+}$ & 165.0212 & 165.0214 & -1.21 \\
\hline & $\mathrm{C}_{7} \mathrm{H}_{5} \mathrm{ClN}^{+}$ & 138.0107 & 138.0105 & 1.45 \\
\hline \multirow[t]{13}{*}{ Alprazolam } & $\mathrm{C}_{17} \mathrm{H}_{14} \mathrm{ClN}_{4}^{+}$ & 309.0906 & 309.0902 & 1.29 \\
\hline & $\mathrm{C}_{16} \mathrm{H}_{12} \mathrm{ClN}_{3}^{+\cdot}$ & 281.0719 & 281.0714 & 1.78 \\
\hline & $\mathrm{C}_{17} \mathrm{H}_{14} \mathrm{~N}_{4}^{+\cdot}$ & 274.1212 & 274.1213 & -0.36 \\
\hline & $\mathrm{C}_{15} \mathrm{H}_{12} \mathrm{ClN}_{2}^{+}$ & 255.0682 & 255.0684 & -0.78 \\
\hline & $\mathrm{C}_{15} \mathrm{H}_{8} \mathrm{ClN}_{2}^{+}$ & 251.0369 & 251.0371 & -0.80 \\
\hline & $\mathrm{C}_{14} \mathrm{H}_{10} \mathrm{ClN}_{2}^{+}$ & 241.0526 & 241.0527 & -0.41 \\
\hline & $\mathrm{C}_{14} \mathrm{H}_{10} \mathrm{ClN}^{+\cdot}$ & 227.0499 & 227.0496 & 1.32 \\
\hline & $\mathrm{C}_{14} \mathrm{H}_{7} \mathrm{ClN}^{+}$ & 224.0260 & 224.0262 & -0.89 \\
\hline & $\mathrm{C}_{10} \mathrm{H}_{9} \mathrm{ClN}_{3}^{+}$ & 206.0476 & 206.0480 & -1.94 \\
\hline & $\mathrm{C}_{14} \mathrm{H}_{9} \mathrm{~N}_{2}^{+}$ & 205.0764 & 205.0760 & 1.95 \\
\hline & $\mathrm{C}_{15} \mathrm{H}_{10} \mathrm{~N}^{+}$ & 204.0805 & 204.0808 & -1.47 \\
\hline & $\mathrm{C}_{8} \mathrm{H}_{6} \mathrm{ClN}_{2}^{+}$ & 165.0216 & 165.0214 & 1.21 \\
\hline & $\mathrm{C}_{7} \mathrm{H}_{5} \mathrm{ClN}^{+}$ & 138.0106 & 138.0105 & 0.72 \\
\hline \multirow[t]{11}{*}{ Flubromazolam } & $\mathrm{C}_{17} \mathrm{H}_{13} \mathrm{BrFN}_{4}^{+}$ & 371.0306 & 371.0302 & 1.08 \\
\hline & $\mathrm{C}_{16} \mathrm{H}_{11} \mathrm{BrFN}_{3}^{+\cdot}$ & 343.0114 & 343.0115 & -0.29 \\
\hline & $\mathrm{C}_{14} \mathrm{H}_{9} \mathrm{BrFN}_{2}^{+}$ & 302.9928 & 302.9928 & 0 \\
\hline & $\mathrm{C}_{17} \mathrm{H}_{13} \mathrm{FN}_{4}^{+\cdot}$ & 292.1118 & 292.1119 & -0.34 \\
\hline & $\mathrm{C}_{17} \mathrm{H}_{12} \mathrm{FN}_{2}^{+}$ & 263.0982 & 263.0979 & 1.14 \\
\hline & $\mathrm{C}_{16} \mathrm{H}_{12} \mathrm{FN}^{+\cdot}$ & 237.0951 & 237.0948 & 1.27 \\
\hline & $\mathrm{C}_{14} \mathrm{H}_{8} \mathrm{FN}_{2}^{+}$ & 223.0670 & 223.0666 & 1.79 \\
\hline & $\mathrm{C}_{15} \mathrm{H}_{9} \mathrm{FN}^{+}$ & 222.0715 & 222.0714 & 0.45 \\
\hline & $\mathrm{C}_{7} \mathrm{H}_{5} \mathrm{BrN}^{+}$ & 181.9600 & 181.9600 & 0 \\
\hline & $\mathrm{C}_{10} \mathrm{H}_{9} \mathrm{~N}_{3}{ }^{+\cdot}$ & 171.0794 & 171.0791 & 1.75 \\
\hline & $\mathrm{C}_{10} \mathrm{H}_{9} \mathrm{~N}^{+\cdot}$ & 143.0732 & 143.0730 & 1.40 \\
\hline
\end{tabular}



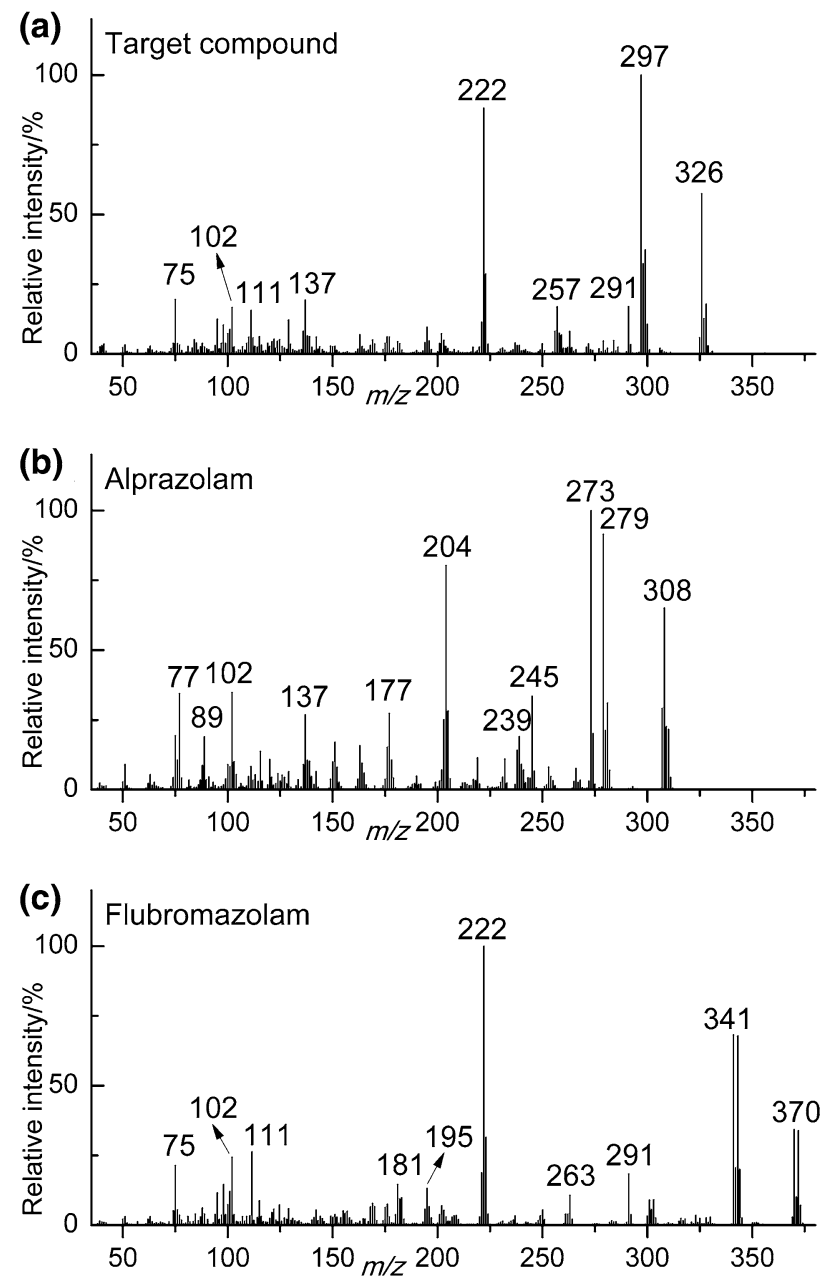

Fig. 3 Mass spectra of the target compound, alprazolam, and flubromazolam obtained by gas chromatography-electron ionization-mass spectrometry

target compound $\left(\mathrm{C}_{17} \mathrm{H}_{12} \mathrm{ClFN}_{4}\right)$ was observed to replace bromine with chlorine. Moreover, the differences in the chemical formulae between the product ions $\mathrm{C}_{16} \mathrm{H}_{11} \mathrm{ClFN}_{3}{ }^{+\cdot}=m / z$ 299.0625, $\mathrm{C}_{17} \mathrm{H}_{13} \mathrm{FN}_{4}{ }^{+\cdot}=m / z$ 292.1124, $\mathrm{C}_{15} \mathrm{H}_{11} \mathrm{ClFN}_{2}{ }^{+}=m / z$ 273.0592, $\mathrm{C}_{15} \mathrm{H}_{7} \mathrm{ClFN}_{2}{ }^{+}=m / z$ 269.0281, $\mathrm{C}_{14} \mathrm{H}_{9} \mathrm{ClFN}_{2}{ }^{+}=m / z$ 259.0437, $\mathrm{C}_{14} \mathrm{H}_{6} \mathrm{ClFN}^{+}=m / z$ 242.0169, $\mathrm{C}_{14} \mathrm{H}_{8} \mathrm{FN}_{2}{ }^{+}=m / z$ 223.0662, and $\mathrm{C}_{15} \mathrm{H}_{9} \mathrm{FN}^{+}=m / z, 222.0714$ of the target compound and the product ions $\mathrm{C}_{16} \mathrm{H}_{12} \mathrm{ClN}_{3}{ }^{+\cdot}=m / z$ 281.0719, $\mathrm{C}_{17} \mathrm{H}_{14} \mathrm{~N}_{4}{ }^{+\cdot}=m / z$ 274.1212, $\mathrm{C}_{15} \mathrm{H}_{12} \mathrm{ClN}_{2}{ }^{+}=m / z$ 255.0682, $\mathrm{C}_{15} \mathrm{H}_{8} \mathrm{ClN}_{2}{ }^{+}=m / z$ 251.0369, $\mathrm{C}_{14} \mathrm{H}_{10} \mathrm{ClN}_{2}^{+}=m / z$ 241.0526, $\mathrm{C}_{14} \mathrm{H}_{7} \mathrm{ClN}^{+}=m / z$ 224.0260, $\mathrm{C}_{14} \mathrm{H}_{9} \mathrm{~N}_{2}{ }^{+}=m / z$ 205.0764, and $\mathrm{C}_{15} \mathrm{H}_{10} \mathrm{~N}^{+}=m / z 204.0805$ of alprazolam were consistent with the presence of fluorine substituent. The chemical formulae were the same between the product ions $\mathrm{C}_{10} \mathrm{H}_{9} \mathrm{ClN}_{3}{ }^{+}=m / z$ 206.0478, $\mathrm{C}_{8} \mathrm{H}_{6} \mathrm{ClN}_{2}{ }^{+}=m / z$ 165.0212, and $\mathrm{C}_{7} \mathrm{H}_{5} \mathrm{ClN}^{+}=m / z$ 138.0107 of the target compound and the product ions $\mathrm{C}_{10} \mathrm{H}_{9} \mathrm{ClN}_{3}{ }^{+}=m / z$ 206.0476, $\mathrm{C}_{8} \mathrm{H}_{6} \mathrm{ClN}_{2}{ }^{+}=m / z$ 165.0216, and $\mathrm{C}_{7} \mathrm{H}_{5} \mathrm{ClN}^{+}=m / z 138.0106$ of alprazolam. The similar phenomenon was observed between the target compound and flubromazolam. The differences in the chemical formulae between the product ions $\mathrm{C}_{16} \mathrm{H}_{11} \mathrm{ClFN}_{3}{ }^{+\cdot}=m / z$ 299.0625, $\mathrm{C}_{14} \mathrm{H}_{9} \mathrm{ClFN}_{2}{ }^{+}=m / z$ 259.0437, and $\mathrm{C}_{7} \mathrm{H}_{5} \mathrm{ClN}^{+}=m / z$ 138.0107 of the target compound and the product ions $\mathrm{C}_{16} \mathrm{H}_{11} \mathrm{BrFN}_{3}{ }^{+\cdot}=m / z \quad 343.0114, \mathrm{C}_{14} \mathrm{H}_{9} \mathrm{BrFN}_{2}{ }^{+}=m / z$ 302.9928, and $\mathrm{C}_{7} \mathrm{H}_{5} \mathrm{BrN}^{+}=m / z 181.9600$ of flubromazolam were consistent with replacing bromine with chlorine. The chemical formulae were the same between the product ions $\mathrm{C}_{17} \mathrm{H}_{13} \mathrm{FN}_{4}^{+\cdot}=m / z$ 292.1124, $\mathrm{C}_{17} \mathrm{H}_{12} \mathrm{FN}_{2}{ }^{+}=m / z$ 263.0980, $\mathrm{C}_{16} \mathrm{H}_{12} \mathrm{FN}^{+\cdot}=m / z$ 237.0949, $\mathrm{C}_{14} \mathrm{H}_{8} \mathrm{FN}_{2}{ }^{+}=m / z$ 223.0662, and $\mathrm{C}_{15} \mathrm{H}_{9} \mathrm{FN}^{+}=m / z 222.0714$ of the target compound and the product ions $\mathrm{C}_{17} \mathrm{H}_{13} \mathrm{FN}_{4}{ }^{+\cdot}=m / z, 292.1118, \mathrm{C}_{17} \mathrm{H}_{12} \mathrm{FN}_{2}{ }^{+}=m / z$ 263.0982, $\mathrm{C}_{16} \mathrm{H}_{12} \mathrm{FN}^{+\cdot}=m / z$ 237.0951, $\mathrm{C}_{14} \mathrm{H}_{8} \mathrm{FN}_{2}{ }^{+}=m / z$ 223.0670, and $\mathrm{C}_{15} \mathrm{H}_{9} \mathrm{FN}^{+}=m / z 222.0715$ of flubromazolam (Table 1; Fig. 2b-d). These findings indicated that the target compound was an alprazolam derivative with one fluorine atom substituted on the phenyl ring without chlorine atom and a flubromazolam derivative with replacing bromine with chlorine, i.e., flualprazolam (Fig. 1).

The electron ionization mass spectrum of the target compound (Fig. 3a) was also compared with those of alprazolam (Fig. 3b) and flubromazolam (Fig. 3c). The differences between the fragment ions at $m / z$ 326, 297, 291, 257, and 222 in the target compound and the fragment ions at $m / z$ $308,279,273,239$, and 204 in alprazolam were 18, respectively, all due to the presence of the fluorine atom. The differences between the fragment ions at $m / z$ 326, 297, and 137 in the target compound and the fragment ions at $\mathrm{m} / \mathrm{z} 370$, 341 , and 181 in flubromazolam were 44, respectively, all due to replacement of bromine by chlorine. The fragment ions at $m / z 291,222,111,102$, and 75 in the target compound are also observed in flubromazolam. These observations support the assumption that the target compound was substituted by one fluorine atom on the phenyl ring as compared with alprazolam and by replacing bromine with chlorine as compared with flubromazolam.

The specific substitution positions of the fluorine atom were further elucidated by NMR analysis. We compared the chemical shifts of the corresponding carbons of the target compound with those observed in the alprazolam. The chemical shifts of C-6a to C-10a in the target compound were similar to the phenyl ring with chlorine atom present in the alprazolam (Table 2), but different from the aromatic protons on another phenyl ring. The presence of fluorine atom resulted in the splitting of the peaks in the ${ }^{13} \mathrm{C}$ spectrum. For the target compound, doublet splitting of the carbon signal in the aromatic carbon region and spin-spin coupling constants $\left(J_{\mathrm{C}-\mathrm{F}}=249.7 \mathrm{~Hz} ; J_{\mathrm{C}-\mathrm{F}}=11.5\right.$ and $\left.21.3 \mathrm{~Hz}\right)$ were characteristic for ${ }^{19} \mathrm{~F}-{ }^{13} \mathrm{C}$ interactions [12]. In Fig. 4, one quaternary carbon that directly connected with the fluorine substituents was seen at $\delta_{\mathrm{C}} 161.7 \mathrm{ppm}$. The comparison 


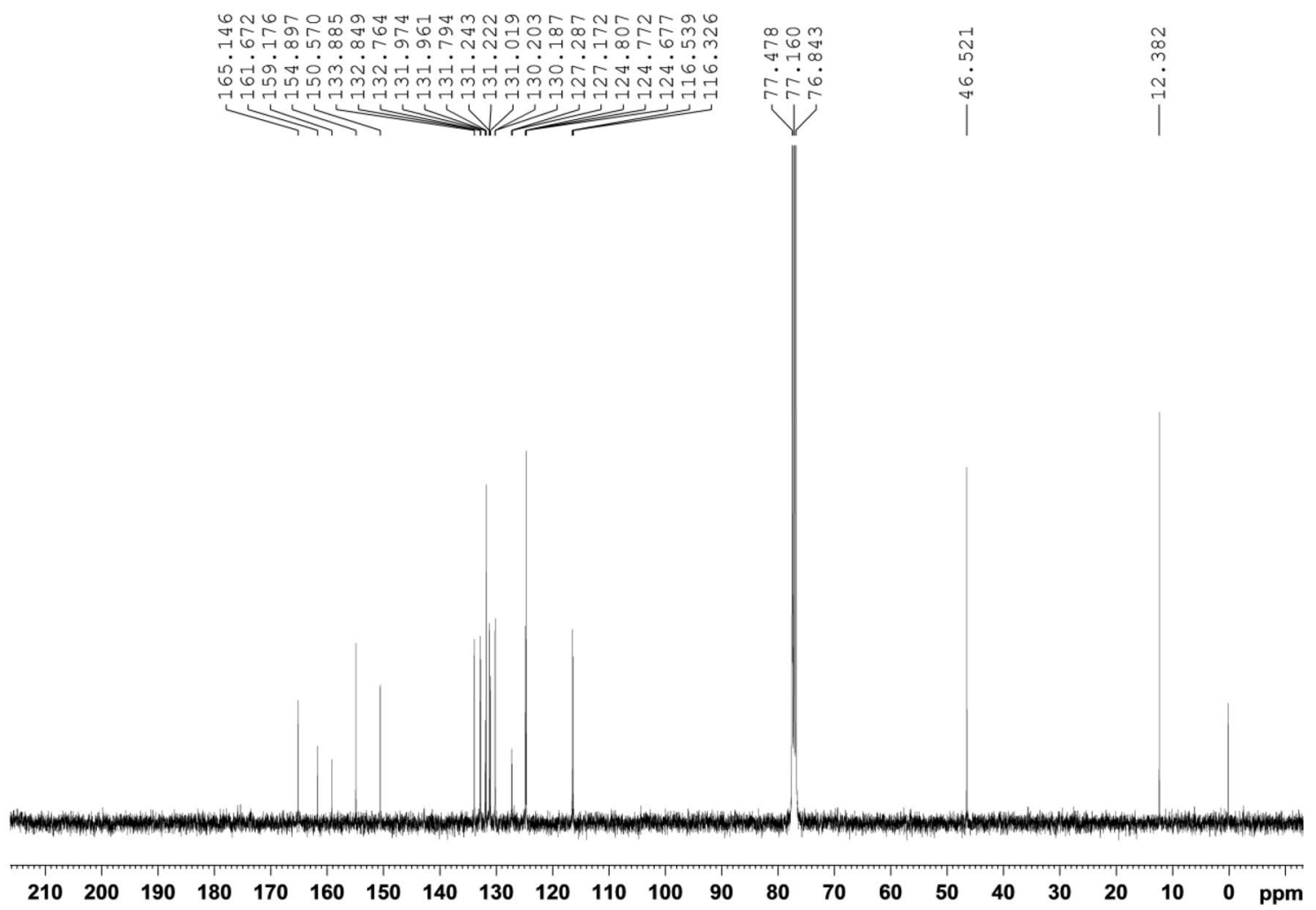

Fig. $4{ }^{13} \mathrm{C}$ nuclear magnetic resonance (NMR) spectrum (100 MHz, $\left.\mathrm{CD}_{3} \mathrm{OD}\right)$ of the target compound
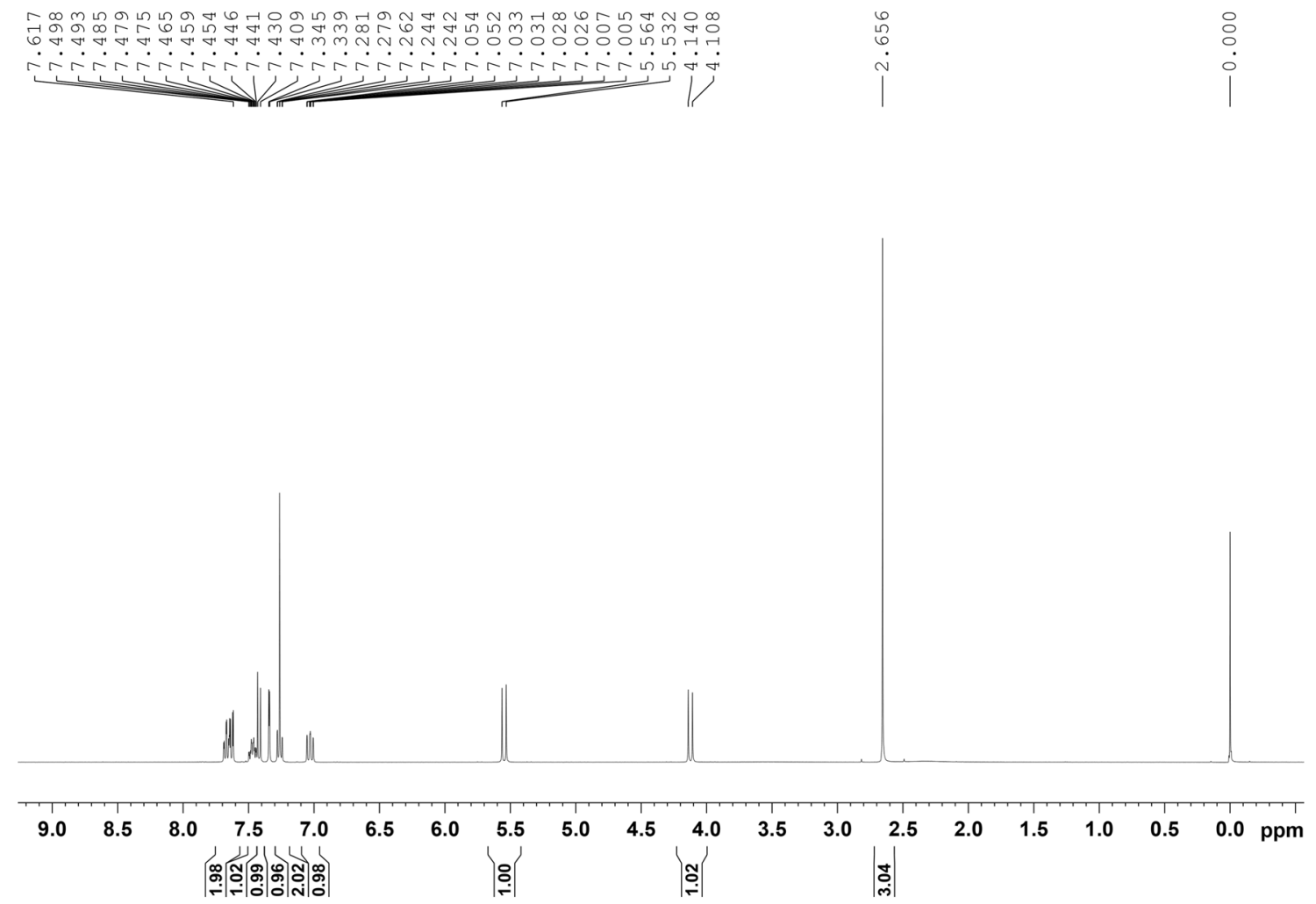

Fig. $5{ }^{1} \mathrm{H}$ NMR spectrum (400 MHz, $\left.\mathrm{CD}_{3} \mathrm{OD}\right)$ of the target compound 
of the DEPT and ${ }^{13} \mathrm{C}$ spectra (Fig. 4) proved the presence of another aromatic quaternary carbon (127.2 ppm) with C-F spin-spin coupling constants of $11.5 \mathrm{~Hz}$, which were characteristic for $J_{\mathrm{C}-\mathrm{F}}$ spin-spin coupling [12]. Therefore, this indicated that fluorine atom was substituted in the ortho position of the phenyl moieties (Fig. 5). Using both the 1D and 2D NMR spectra, the final assignments of the observed carbon and hydrogen chemical shifts for the target compound are shown in Table 2.

On the basis of the above instrumental data, the target compound was identified to be flualprazolam.

\section{Conclusions}

In this study, a designer benzodiazepine 8-chloro-6-(2fluorophenyl)-1-methyl-4H-[1,2,4]triazolo[4,3-a][1,4] benzodiazepine (flualprazolam) was identified in illegal products seized in an anesthesia robbery case. The applied procedure for structure elucidation was based on LC-QTOF-MS, GC-MS, and NMR in the absence of a reference substance. Analytical data were presented to assist forensic laboratories that encounter these newly emerging compounds in casework. BZDs are a rather safe class of drug; however, for most of the DBZDs, no clinical trials were published, and therefore, severe side effects or unexpected toxicities cannot be ruled out. Flualprazolam

Table $2{ }^{1} \mathrm{H}$ and ${ }^{13} \mathrm{C}$ nuclear magnetic resonance chemical shifts and diagnostic correlations in two-dimensional spectra of the target compound

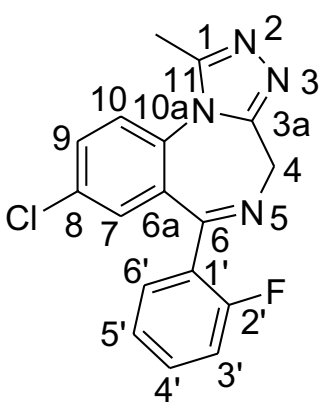

\begin{tabular}{|c|c|c|c|c|}
\hline Position & ${ }^{13} \mathrm{C}(\delta / \mathrm{ppm})$ & $\begin{array}{l}{ }^{1} \mathrm{H}\left(\delta / \text { ppm, protons, multiplicity }{ }^{\mathrm{a}} \text {, coupling constants }\right) \\
{ }^{1} \mathrm{H} /{ }^{13} \mathrm{C}-\mathrm{HSQC}^{\mathrm{c}}\end{array}$ & ${ }^{1} \mathrm{H} /{ }^{13} \mathrm{C}-\mathrm{HMBC}{ }^{\mathrm{b}}$ & $\begin{array}{l}\text { Alprazolam- } \\
{ }^{13} \mathrm{C}\end{array}$ \\
\hline 1 & 150.6 & - & - & \\
\hline $3 \mathrm{a}$ & 154.9 & - & - & \\
\hline 4 & 46.5 & $5.55,1 \mathrm{H}, \mathrm{d}, J=12.8 \mathrm{~Hz}$ and $4.12,1 \mathrm{H}, \mathrm{d}, J=12.8 \mathrm{~Hz}$ & $3 a, 6,1^{\prime}$ & \\
\hline 6 & 165.1 & - & - & \\
\hline $6 a$ & $132.0, \mathrm{~d}, J=1.3 \mathrm{~Hz}$ & - & - & 132.0 \\
\hline 7 & $130.2, \mathrm{~d}, J=1.6 \mathrm{~Hz}$ & $7.34,1 \mathrm{H}, \mathrm{d}, J=2.4 \mathrm{~Hz}$, overlapped & $6,8,9,10 \mathrm{a}$ & 132.7 \\
\hline 8 & 133.9 & - & - & 134.6 \\
\hline 9 & 131.8 & $7.63,1 \mathrm{H}, \mathrm{dd}, J=8.8,2.4 \mathrm{~Hz}$ & $7,8,10 \mathrm{a}$ & 133.3 \\
\hline 10 & 124.7 & $7.42,1 \mathrm{H}, \mathrm{d}, J=8.4 \mathrm{~Hz}$ & $6 a, 8$ & 126.9 \\
\hline $10 \mathrm{a}$ & 131.0 & - & - & 133.4 \\
\hline $1^{\prime}$ & $127.2, \mathrm{~d}, J=11.5 \mathrm{~Hz}$ & - & - & \\
\hline $2^{\prime}$ & $161.7, \mathrm{~d}, J=249.7 \mathrm{~Hz}$ & - & - & \\
\hline $3^{\prime}$ & $116.5, \mathrm{~d}, J=21.3 \mathrm{~Hz}$ & $7.03,1 \mathrm{H}, \mathrm{ddd}, J=10.4,8.4,0.8 \mathrm{~Hz}$ & $1^{\prime}, 2^{\prime}, 5^{\prime}$ & \\
\hline $4^{\prime}$ & $132.8, \mathrm{~d}, J=8.5 \mathrm{~Hz}$ & $7.47,1 \mathrm{H}, \mathrm{m}$ & $2^{\prime}, 6^{\prime}$ & \\
\hline $5^{\prime}$ & $124.8, \mathrm{~d}, J=3.5 \mathrm{~Hz}$ & $7.26,1 \mathrm{H}, \mathrm{td}, J=7.4,0.8 \mathrm{~Hz}$, overlapped & $1^{\prime}, 3^{\prime}$ & \\
\hline $6^{\prime}$ & $131.2, \mathrm{~d}, J=2.1 \mathrm{~Hz}$ & $7.67,1 \mathrm{H}, \mathrm{td}, J=7.6,1.6 \mathrm{~Hz}$, overlapped & $6,2^{\prime}, 4^{\prime}$ & \\
\hline $\mathrm{CH}_{3}$ & 12.4 & $2.66,3 \mathrm{H}, \mathrm{s}$ & 1 & \\
\hline
\end{tabular}

Recorded in $\mathrm{CD}_{3} \mathrm{OD}$ at $400 \mathrm{MHz}\left({ }^{1} \mathrm{H}\right)$ and $100 \mathrm{MHz}\left({ }^{13} \mathrm{C}\right)$, respectively

${ }^{\mathrm{a}} b r$ broad, $d$ doublet, $m$ multiplet, $s$ singlet, $t$ triplet

${ }^{\mathrm{b}} H M B C$ heteronuclear multiple-bond correlation spectroscopy. The proton signal correlated with the indicated carbons

${ }^{\mathrm{c}} \mathrm{HSQC}$ heteronuclear single-quantum correlation spectroscopy 
is not only used for recreational abuse but also used for criminal offences. It is a DBZD with a strong and longlasting depressive effect on the CNS representing a high risk of severe poisoning. This phenomenon warrants our attention.

Acknowledgements We are gratefully acknowledging the Fundamental Research Fund of the Institute of Forensic Science of the Ministry of Public Security (2017JB030).

\section{Compliance with ethical standards}

Conflict of interest There are no financial or other relations that could lead to a conflict of interest.

Ethical approval This article does not contain any studies with human participants or animals performed by any of the authors.

Open Access This article is distributed under the terms of the Creative Commons Attribution 4.0 International License (http://creativeco mmons.org/licenses/by/4.0/), which permits unrestricted use, distribution, and reproduction in any medium, provided you give appropriate credit to the original author(s) and the source, provide a link to the Creative Commons license, and indicate if changes were made.

\section{References}

1. United Nations Office on Drugs and Crime (UNODC) (2019) Current NPS threats, vol. I March 2019. https://www.unodc.org/pdf/ opioids-crisis/Current_NPS_Threats_-_Volume_I.pdf. Accessed 6 Mar 2019

2. United Nations Office on Drugs and Crime (UNODC) (2013) The challenge of new psychoactive substances. https://www.unodc .org/documents/scientific/NPS_2013_SMART.pdf. Accessed Mar 2013
3. Manchester KR, Lomas EC, Waters L, Dempsey FC, Maskell PD (2018) The emergence of new psychoactive substance (NPS) benzodiazepines: a review. Drug Test Anal 10:37-53. https://doi. org/10.1002/dta.2211

4. Moosmann B, King LA, Auwärter V (2015) Designer benzodiazepines: a new challenge. World Psychiatry 14:248. https://doi. org/10.1002/wps.20236 (open access article)

5. European Monitoring Centre for Drugs and Drug Addiction (EMCDDA) (2010) Benzodiazepines drug profile. https://www. emcdda.europa.eu/publications/drug-profiles/benzodiazepine. Accessed 20 May 2019

6. Bachhuber MA, Hennessy S, Cunningham CO, Starrels JL (2016) Increasing benzodiazepine prescriptions and overdose mortality in the United States, 1996-2013. Am J Public Health 106:686-688. https://doi.org/10.2105/AJPH.2016.303061

7. Kapil V, Green JL, Le Lait C, Wood DM, Dargan PI (2014) Misuse of benzodiazepines and Z-drugs in the UK. Br J Psychiatry 205:407-408. https://doi.org/10.1192/bjp.bp.114.149252

8. Huppertz LM, Bisel P, Westphal F, Franz F, Auwärter V, Moosmann B (2015) Characterization of the four designer benzodiazepines clonazolam, deschloroetizolam, flubromazolam, and meclonazepam, and identification of their in vitro metabolites. Forensic Toxicol 33:388-395. https://doi.org/10.1007/s1141 9-015-0277-6

9. Łukasik-Głębocka M, Sommerfeld K, Teżyk A, Zielińska-Psuja B, Panieński P, Żaba C (2016) Flubromazolam-a new life-threatening designer benzodiazepine. Clin Toxicol 54:66-68. https://doi. org/10.3109/15563650.2015.1112907

10. Hester JB Jr (1970) Sedative and antispasmodic 6-phenyl-4H-striazolo[4,3-a][1,4]benzodiazepines. DE 2012190, US 3701782

11. SciFinder (2019) American Chemical Society. https://scifinder. cas.org. Accessed 20 May 2019

12. Pretsch E, Bühlmann P, Badertscher M (2009) Structure determination of organic compounds: tables of spectral data, 4 th edn. Springer, Berlin, pp 102-103

Publisher's Note Springer Nature remains neutral with regard to jurisdictional claims in published maps and institutional affiliations. 